\title{
The Path Direction Control System for Lanange Jagad Dance Robot Using the MPU6050 Gyroscope Sensor
}

\author{
Ibnu Rifajar a,1,*, Abdul Fadlil a,2 \\ aUniversitas Ahmad Dahlan, Bantul 55191, Yogyakarta, Indonesia \\ 1 ibnu.rifajar11@gmail.com; ${ }^{2}$ fadli1@ee.uad.ac.id \\ *Corresponding Author
}

ARTICLE INFO

\section{Article history}

Received 29 January 2021

Revised 15 February 2021

Accepted 21 February 2021

Keywords

KRSTI;

Robot Humanoid;

Gyroscope;

MPU6050;

Controller

\begin{abstract}
The ability to walk straight on a dance robot is very important considering that in competitions, dance robots are required to be able to walk through several zones starting from the starting zone and ending with the closed zone. Therefore, a control system is needed in the Lanange Jagad dance robot so that the robot can control the direction of its walking motion and reduce errors in dance motion while walking on the dance robot. This control system uses a reading value based on the orientation of the rotating motion on the yaw angle axis on the MPU6050 gyroscope sensor which will later be used as a corrector for dance robots when performing various dance movements while walking in the competition arena. From the results of the overall test of the Lanange Jagad dance robot after adding the road direction control system, the percentage of the success rate in the battery power supply condition is 12 volts to 12.6 volts by $100 \%$ with the greater the battery power supply, the error in the robot's final angle average to The starting angle of the robot is getting smaller and the percentage of the success rate at the slope of the 00 to 40 race arena is $93.3 \%$. With the tilted race arena, the error in the mean error of the robot's final angle to the starting angle of the robot is also greater, so it can be concluded that the robot can be controlled direction of walking and can walk straight to the finish in the closed zone.
\end{abstract}

This is an open access article under the CC-BY-SA license.

\section{Introduction}

Technological developments are increasingly developing, especially in the field of control systems. One of these developments is the field of robotics. Various types of robots have been created and developed to meet human needs. Starting from robots that can help with homework, industrial robots, robots for entertainment and humanoid robots [1][2]. Humanoid robots are robots that have body parts like humans because they have the construction of legs, head, body, hands and are able to move like humans [3]. 
The Indonesian Robotics Competition (KRI) is a competition organized by the Ministry of Research, Technology and Higher Education of the Republic of Indonesia (Kemenristek Dikti). In KRI there are several categories, one of which is the Indonesian Dance Robot Competition (KRSTI) which uses humanoid robots. The competition in this category is designing, building and programming robots that are combined with elements of Indonesian art and culture, especially dance, which is well known in Indonesia [4] [5].

In the Indonesian Dance Robot Contest, the Ahmad Dahlan University robot team participated in the competition in the KRSTI category and Lanange Jagad was the name of the KRSTI robot from Ahmad Dahlan University (Fig. 1). The ability to walk on dance robots is very important considering that in competitions, dance robots are required to be able to walk through several zones starting from the starting zone and ending with the closed zone. Therefore, a control system is needed in the Lanange Jagad dance robot so that the robot can be controlled in the direction of its walking motion and reduce errors in dance motion while walking on the dance robot.

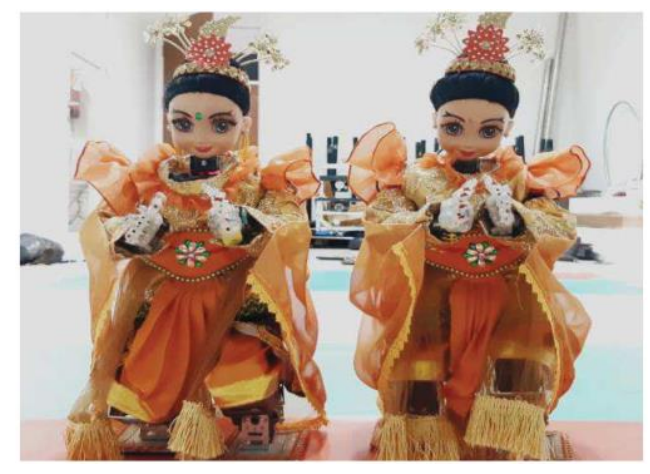

Figure 1. Ahmad Dahlan University Dance Humanoid Robot

This control system uses a reading value based on the orientation of the rotating motion on the yawn angle axis on the MPU6050 sensor which will later be used as a controller for the dance robot when performing various dance movements while walking in the race arena. The MPU 6050 sensor is a module that can integrate an accelerometer and a gyroscope (Gyroscope) [6]. The sensor is a tool that measures and maintains direction based on the principle of angular momentum [7][8][9]. In this study, the gyroscope sensor will be used as feedback for the robot controller so that it can run straight.

\section{Method}

\subsection{Control System Block Diagram}

A gyro sensor is a device that measures or maintains direction. The gyroscope can read movement based on gravity, or it can detect the user's movement, is used to measure direction based on the principle of angular momentum, and has sensitive outputs on the angular velocity of the $\mathrm{x}, \mathrm{y}$ and $\mathrm{z}$ axes or angular phi (roll), theta (pitch) and angle psi (yaw) [10]. In this control system uses a reading value based on the orientation of the rotating motion on the yaw angle axis on the MPU6050 gyroscope sensor which will later be used as a reference as a controller for dance robots when performing various dance movements while walking.

When the system is running, the system will initialize the program and activate the gyroscope sensor to send data to the microcontroller for processing. The system takes the value of the gyroscope sensor reading which is useful for knowing changes in position (angle). Value in the form of analog is converted to digital via the ADC (Analog to Digital Converter) pin via the 
microcontroller [11]. After obtaining the yaw angle value from the gyroscope sensor reading, the next process is to provide a declaration of commands for motion calls or movements based on the gyroscope sensor readings for the robot controller.

The robot control system block diagram is shown in Fig. 2. The set point value is the zerodegree angle, that is, the robot must move in a straight line. The sensor will provide a feedback value to calculate the error value as controller input. The controller will calculate the control value to be sent to the servo motor and correct the robot's movement so that it moves straight.

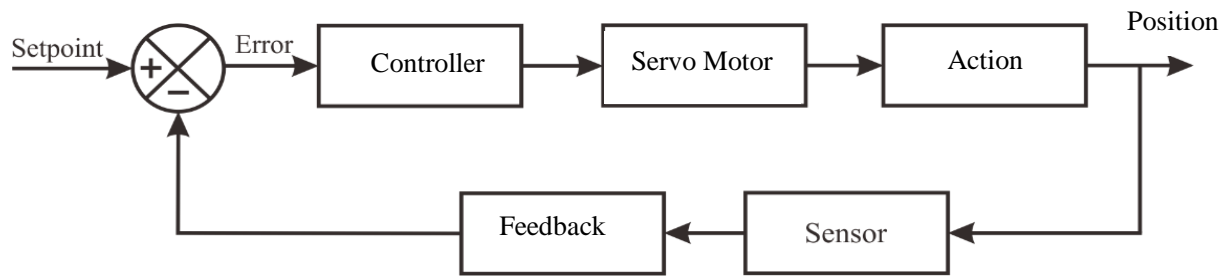

Figure 2. Control System Block Diagram

The angular velocity measurement system consists of a sensor as an element for measuring angular velocity and an Arduino as a data acquisition. The output data from the sensor is received by Arduino and processed according to the coding inputted in the Arduino software. The physical value of the angle will appear on the Arduino software interface screen.

The output from the gyroscope is data in the form of angular velocity. The vector quantity representing the angular frequency of the object and its axis of rotation can be called the angular velocity. The SI unit for angular velocity is radians / second, although it can also be measured in degrees per second, revolutions per second, degrees per hour and more [12].

$$
\theta=\theta_{0}+\omega \mathrm{t}
$$

where $\theta$ is the angle $\left({ }^{\circ}\right), \theta_{0}$ is the initial angle $\left({ }^{\circ}\right), \omega$ is the angular velocity $\left({ }^{\circ} / \mathrm{s}\right)$ and $t$ is the time (s).

\subsection{System Design}

In this study using a humanoid robot design, because humanoid robots are robots whose designs are like the human body and can be controlled so that the robot's movements can resemble humans [13]. Robot Design is shown in Fig. 3.

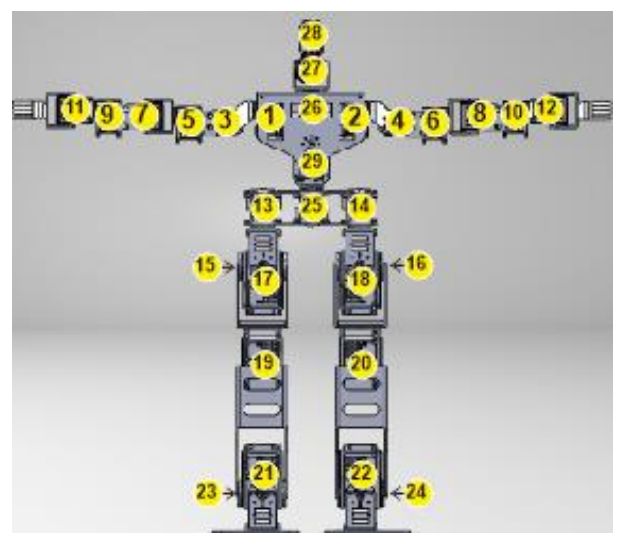

Figure 3. Mechanical Design Robot

Information on the placement of the dynamixel position on the humanoid robot according to Fig. 3 can be seen at Table 1. The design of the MPU6050 gyroscope sensor positioning position 
is that the initial position of the angle contained in the sensor matches the position of the robot standing so that the data issued by the MPU6050 sensor is appropriate and accurate. The MPU6050 gyroscope sensor will be placed at the bottom of servo number 25 or in the middle waist servo so that it can detect the movement of the robot while walking. The $\mathrm{x}, \mathrm{y}$ and $\mathrm{z}$ axes of the gyroscope sensor are shown in Fig. 4.

Table 1. Robot Servo Position

\begin{tabular}{ccc}
\hline Servo Number & $\begin{array}{c}\text { Dynamixel } \\
\text { Position }\end{array}$ & Dynamixel Type \\
\hline 1 until 12 & Hand & Dynamixel XL-320 \\
$13,14,25$ & Waist & Dynamixel MX-28AT \\
15 until 24 & Foot & Dynamixel MX-64AT \\
26 until 28 & Head & Dynamixel XL-320 \\
29 & Stomach & Dynamixel MX-28AT \\
\hline
\end{tabular}

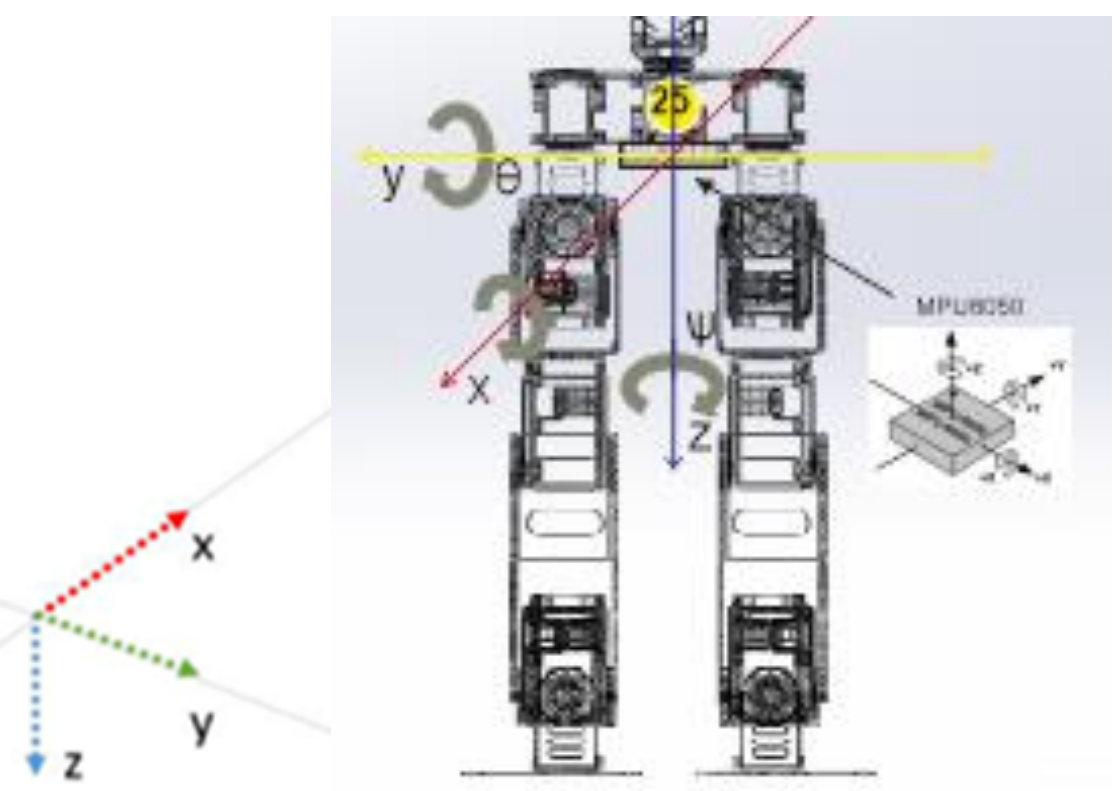

Figure 4. MPU6050 Location

MPU6050 gyro sensor placement is based on two-coordinate adjustment. The first coordinates are the coordinates on earth, because the coordinates of the earth are Cartesian coordinates relative to the earth's surface. The MPU6050 gyro sensor coordinate system is a coordinate sensor placed on the Lanange Jagad robot frame. By determining the two coordinates so that the Euler angle can be applied, the conversion of z-y-x rotation, or it can be said that the yaw angle $(\psi)$, pitch $(\theta)$ and roll $(\phi)$ are the euler angles used in the positioning of the sensor.

\subsection{Wiring Diagram}

In this section, the humanoid robot electronic system will be designed using components consisting of the MPU6050 gyroscope sensor, Arduino Mega 2560 Pro, OpenCM9.04, OpenCM 485 EXP, Li-Po $3800 \mathrm{mAh}$ battery and Dynamixel servo. Lanange Jagad dance art robot, using Arduino Mega 2560 Pro as the main robot controller combined with OpenCM9.04. This controller acts as the main control for the behavior of the robot which has been programmed in it. The communication used on the two controllers is SPI communication, while the MPU6050 module with the Arduino Mega 2560 Pro uses I2C communication. The system wiring diagram is shown in Fig. 5. 


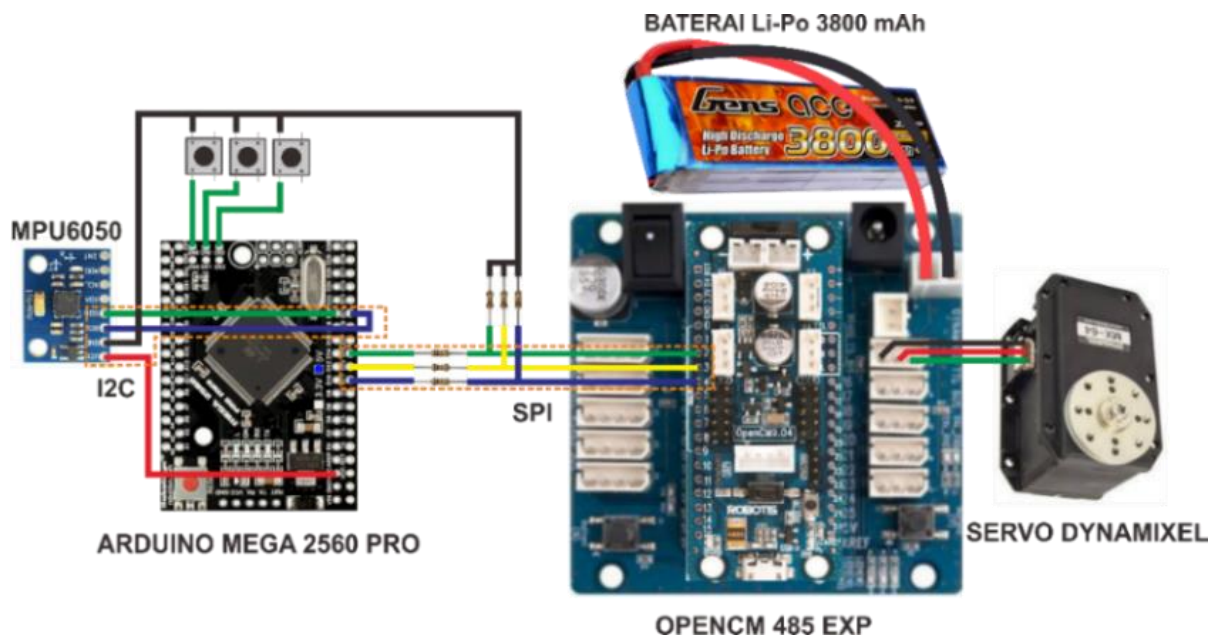

Figure 5. Wiring Diagram

The Arduino Mega 2560 Pro uses pin 10, pin 12, and pin 14 while on OpenCM9.04 it uses pin 2, pin 3, and pin 4 as SPI communications. The Arduino Mega 2560 Pro uses pin 20 and pin 21 while the MPU6050 module uses SDA and SCL pins, as I2C communication places. Making a program that will be downloaded into OpenCM9.04 and the Arduino Mega 2560 Pro board which has the OpenCM9.04 library installed.

The MPU6050 gyroscope sensor will be connected to the Arduino MEGA 2560 PRO so that the reading data from the sensor can be processed. The results of sensor reading data processing carried out by the microcontroller will provide an output value in the form of a psi (yaw) angle which will later be used as a reference for motion calls that have been made on the robot according to what has been declared in the program. For the voltage source of the Lanange Jagad dance robot system, it uses a power supply from a $12 \mathrm{~V}$ lipo battery.

\subsection{Algorithm}

Based on Fig. 6, the system flowchart shows that when the robot is turned on in the starting position and when the start button, the robot will initialize the program, namely the ready movement, read the gyro sensor and perform a calibration to adjust the gyroscope sensor reading value in the direction facing the robot. After the initialization process is complete the robot will read the value from Bluetooth, if the Bluetooth value is equal to 1 then the robot will move according to what has been declared in the program to read the yaw angle on the gyroscope sensor and the robot will respond by moving forward, walking right, and walking left until the program is finished.

\subsection{Gyroscope Configuration}

Before using the gyroscope sensor, it is necessary to carry out a calibration process on the sensor to obtain a calibration factor, then the gyroscope must be compensated by ZRO to produce $0 \% \mathrm{~s}$ stationary (not rotating) sensor output data. When the gyroscope rotates clockwise along one axis (that is, the $\mathrm{z}$ (yaw) axis), the voltage output decreases. At the same time, if it rotates counterclockwise, the output voltage becomes high. This value changes according to the rotation speed of the gyroscope.

The first step in sensor calibration is finding the offset value. Get this offset value when the device is in a horizontal position. The offset value function is used to obtain the offset angle. The MPU6050 module is used in this study. The use of this module is easier. After entering the offset value into the program, adjust the original data value within the range set by the sensor. 
Table 2 Represents the full-scale range of the output of the gyroscope. The gyroscope range consists of $250^{\circ} / \mathrm{s}, 500^{\circ} / \mathrm{s}, 1000^{\circ} / \mathrm{s}, 20000^{\circ} / \mathrm{s}$. Selection of the range is adjusted based on the needs in the program. In this study using a range of $250^{\circ} / \mathrm{s}$.

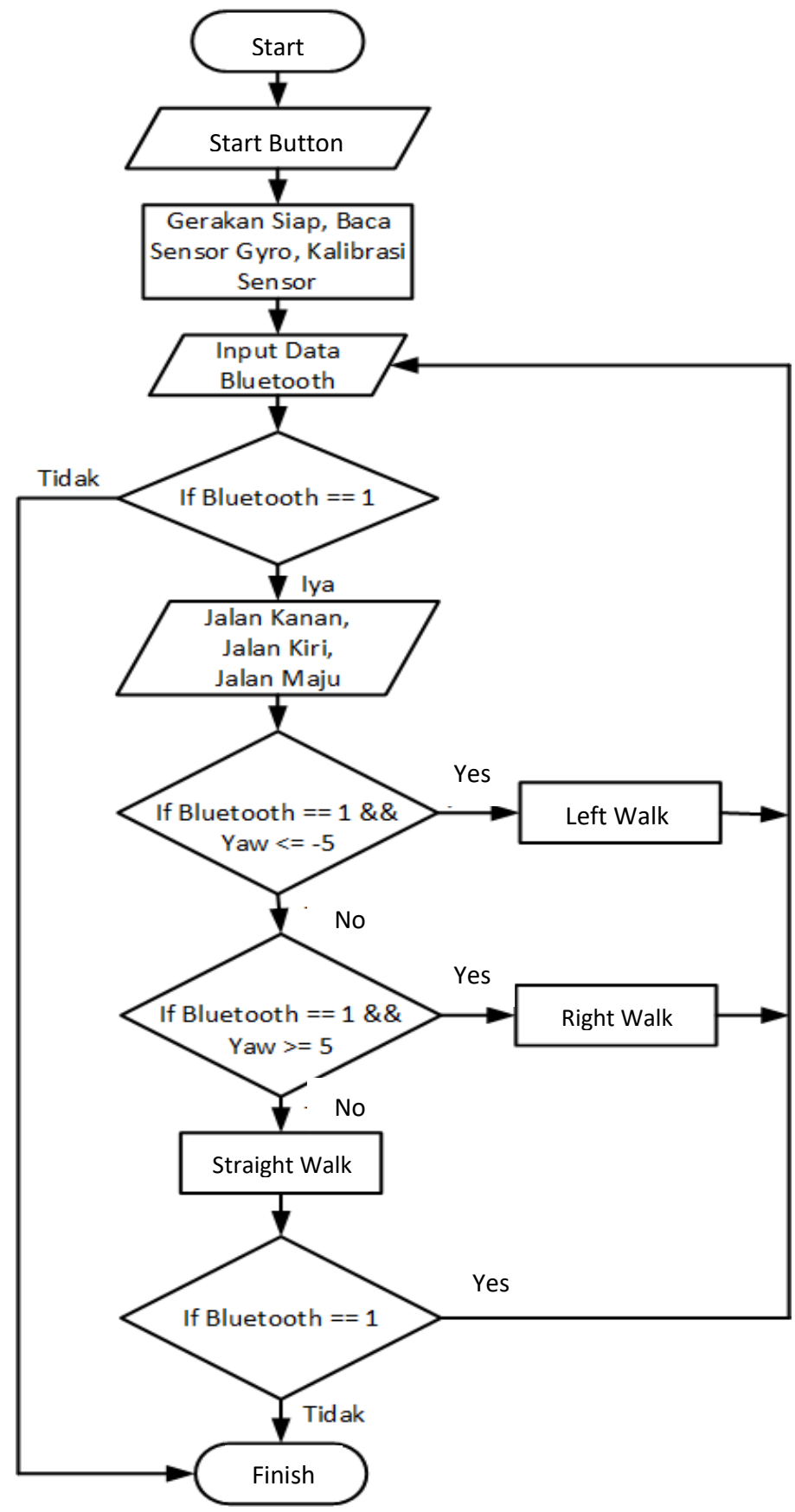

Figure 6. Flowchart

Table 2. Configuration of Gyroscope MPU6050

\begin{tabular}{cc}
\hline FS_SEL & Full Scale Range \\
\hline 0 & $250 \% \mathrm{~s}$ \\
1 & $500 \% \mathrm{~s}$ \\
2 & $1000 \% \mathrm{~s}$ \\
3 & $20000 \% \mathrm{~s}$ \\
\hline
\end{tabular}




\section{Result and Discussion}

This research was conducted based on data samples from the KRSTI Lanange Jagad robot while performing dances and walking continuously and varied. The research robot is shown in Fig. 7.

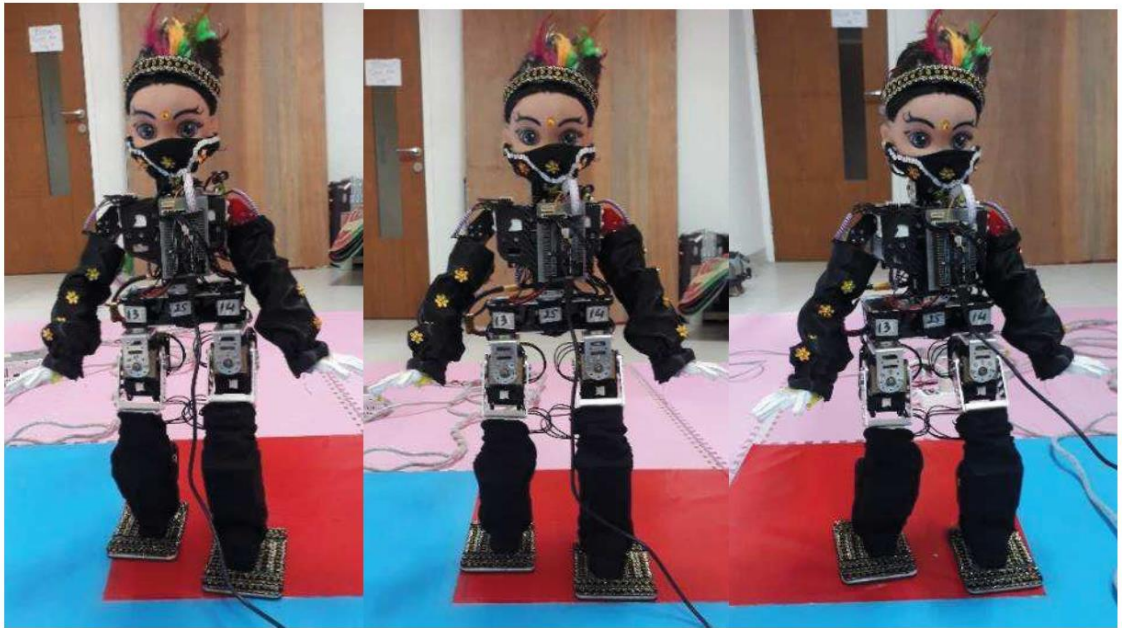

Figure 7. Humanoid Robot for Dance

\subsection{Sensor Testing}

Testing on the MPU6050 sensor (Fig. 8) is carried out by rotating the z-axis angle to become the psi (yaw) angle. The protractor is rotated with an angle of $10^{\circ}$ starting from an angle of $-90^{\circ}$ to an angle of $90^{\circ}$. Each corner was tested 5 times with a test time span of 1 minute. This is done to determine the reading from the gyroscope sensor to the yaw angle so that accurate data and sensor output responses are obtained as needed. The measurement results are shown in Table 3.

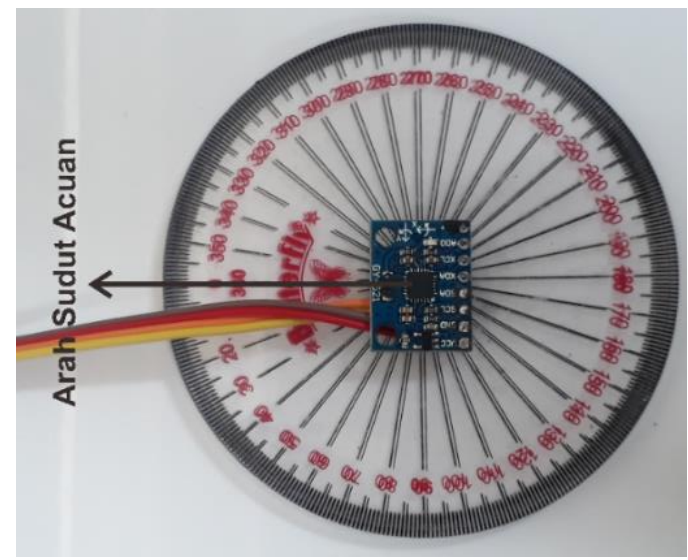

Figure 8. Testing the sensor against the protractor angle

Table 3. Sensor Testing Data at Yaw Angle

\begin{tabular}{|c|c|c|c|c|c|c|c|}
\hline Data retrieval & \multicolumn{5}{|c|}{ Sensor Readings $\left(^{\circ}\right)$} & $\mid$ Average value $\left(^{\circ}\right)$ & |Error| $\left(^{\circ}\right)$ \\
\hline Angle of Reference $\left(^{\circ}\right)$ & 1 & 2 & 3 & 4 & 5 & & \\
\hline-90 & -90.15 & -90.43 & -90.75 & -91.11 & -91.51 & 91.11 & 01.11 \\
\hline-80 & -80.50 & -80.84 & -81.16 & -81.56 & -81.87 & 81.19 & 01.19 \\
\hline-70 & -70.78 & -71.24 & -71.64 & -71.95 & -72.25 & 71.57 & 01.57 \\
\hline-60 & -60.57 & -60.85 & -61.13 & -61.45 & -61.77 & 61.15 & 1.15 \\
\hline
\end{tabular}




\begin{tabular}{|c|c|c|c|c|c|c|c|}
\hline Data retrieval & \multicolumn{5}{|c|}{ Sensor Readings ( ${ }^{\circ}$ ) } & \multirow[t]{2}{*}{ |Average value| $\left({ }^{\circ}\right)$} & \multirow[t]{2}{*}{ |Error| ( $\left.{ }^{\circ}\right)$} \\
\hline Angle of Reference $\left(^{\circ}\right)$ & 1 & 2 & 3 & 4 & 5 & & \\
\hline-50 & -50.73 & -50.89 & -51.08 & -51.33 & -51.68 & 51.14 & 1.14 \\
\hline-40 & -40.66 & -40.90 & -41.12 & -41.38 & -41.58 & 41.12 & 1.12 \\
\hline-30 & -30.65 & -30.90 & -31.11 & -31.47 & -31.80 & 31.19 & 1.19 \\
\hline-20 & -20.53 & -21.21 & -21.40 & -21.68 & -21.84 & 21.33 & 1.33 \\
\hline-10 & -10.66 & -11.03 & -11.40 & -11.70 & -12.03 & 11.37 & 1.37 \\
\hline 0 & 0.90 & 0.48 & 0.09 & -0.21 & -0.56 & 0.07 & 0.07 \\
\hline 10 & 10.44 & 10.06 & 9.80 & 9.58 & 9.31 & 9.83 & 1.83 \\
\hline 20 & 20.61 & 20.40 & 20.14 & 19.96 & 19.62 & 20.14 & 0.14 \\
\hline 30 & 30.42 & 30.36 & 30.06 & 29.68 & 29.45 & 30.00 & 0.00 \\
\hline 40 & 40.55 & 40.07 & 39.72 & 39.39 & 38.94 & 39.73 & 1.73 \\
\hline 50 & 50.34 & 49.17 & 48.82 & 48.50 & 48.18 & 49.00 & 1.00 \\
\hline 60 & 60.50 & 60.17 & 59.82 & 59.47 & 59.14 & 59.82 & 1.82 \\
\hline 70 & 70.36 & 69.97 & 69.69 & 69.38 & 69.05 & 69.70 & 1.70 \\
\hline 80 & 80.76 & 80.43 & 80.09 & 79.77 & 79.45 & 80.01 & 0.01 \\
\hline 90 & 90.54 & 90.12 & 89.77 & 89.39 & 89.11 & 89.80 & 1.80 \\
\hline \multicolumn{7}{|c|}{ |Average Error| } & 1.17 \\
\hline
\end{tabular}

\subsection{Sensor Readout Degree Range}

The degree ranges of the sensor reading to the robot is to implement the direction towards the robot based on the reading value on the gyroscope sensor. The readings are shown in Table 4.

Table 4. Range of degrees in direction to robot

\begin{tabular}{cccc}
\hline No & Yaw angle value & $\begin{array}{c}\text { Direction Towards } \\
\text { Robot }\end{array}$ & $\begin{array}{c}\text { Robot Movement } \\
\text { Response }\end{array}$ \\
\hline 1 & $-91^{\circ}$ until $-180^{\circ}$ & Facing Back & Retry \\
2 & $-5^{\circ}$ until $-90^{\circ}$ & Left oblique & Right Way \\
3 & $-0^{\circ}$ until $-4^{\circ}$ & Straight ahead & The Way Forward \\
4 & $0^{\circ}$ until $4^{\circ}$ & Straight ahead & The Way Forward \\
5 & $5^{\circ}$ until $90^{\circ}$ & Turn Right & Left Path \\
6 & $91^{\circ}$ until $180^{\circ}$ & Facing Back & Retry \\
\hline
\end{tabular}

In Table 4, the range of degrees towards the robot is obtained from the results of testing the gyroscope sensor based on the orientation of the rotating motion on the z-axis axis and adjusted based on the direction of the sensor facing the robot's direction so that the movement response of the robot can be determined which will be used as a controller for the robot's movement when walking on the robot. arena of the race.

\subsection{Robot Control Testing}

The race arena is a rectangle with a length of $300 \mathrm{~cm}$ and a width of $200 \mathrm{~cm}$, and a height of $100 \mathrm{~cm}$ on the ground. The race arena is shown in Fig. 9. Each race arena will be divided into five parts, namely the starting zone, zone A, zone B, zone C and the closed zone. In the KRSTI robot competition there are several conditions that can interfere with the performance of the dance robot in performing dance movements while walking, namely the condition of the competition arena with an uneven or tilted surface and also the unstable state of the battery power supply in the robot so that it can lead to walking errors in dance robots. in the arena of the race. 


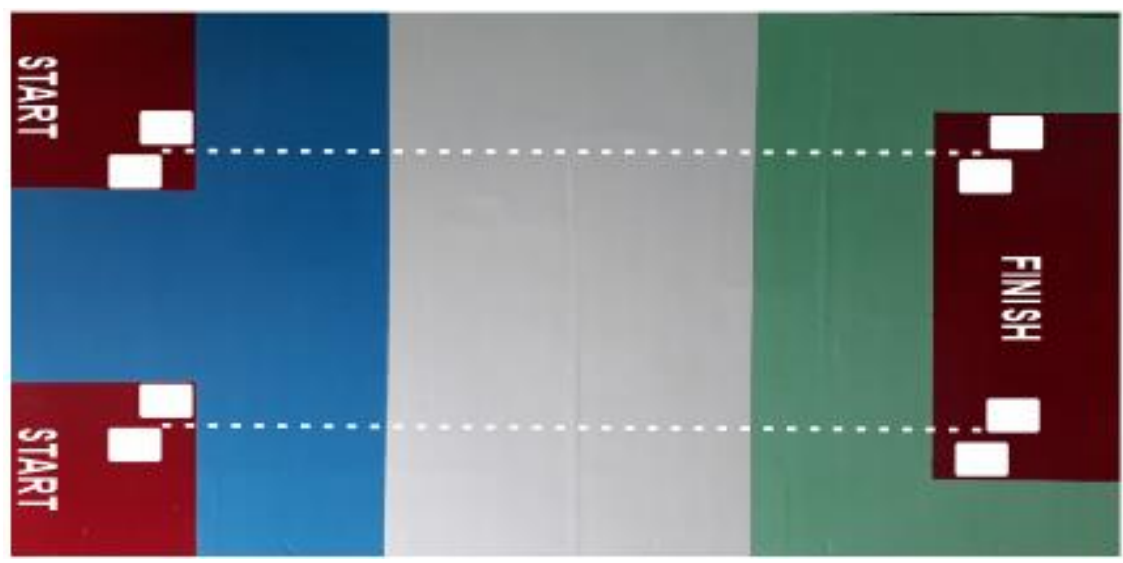

Figure 9. Race arena

\subsection{Conventional Controller}

This test is carried out using a battery power supply condition to see the success rate of the robot before using the control system. The robot will be recorded and the video recording will be used as material in the object marking process using the python application and the results of the plotting of the robot's movement will be obtained in the race arena. The test results are shown in Fig. 10. In this test, it can be seen that the movement of the robot is slightly tilted by several degrees and is not straight.

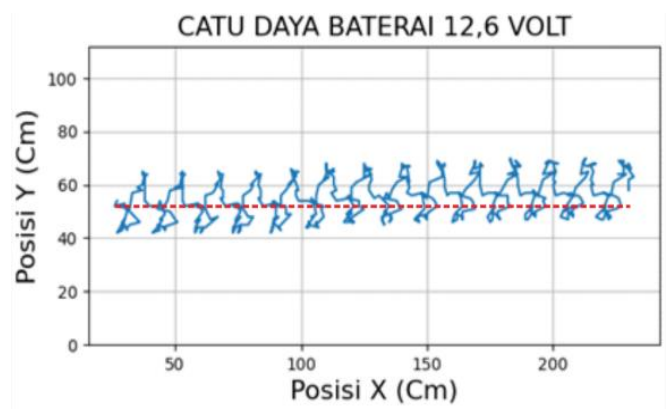

(a)

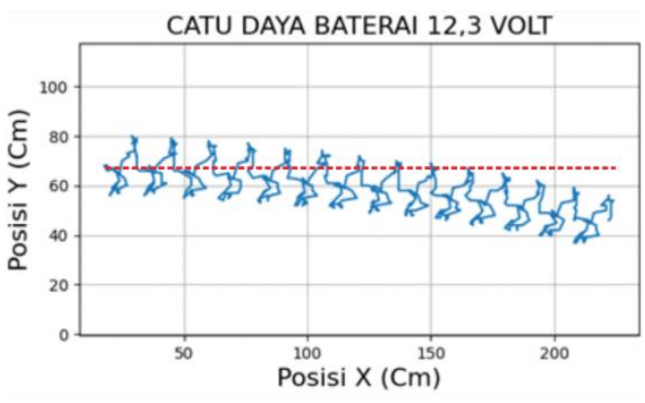

(b)

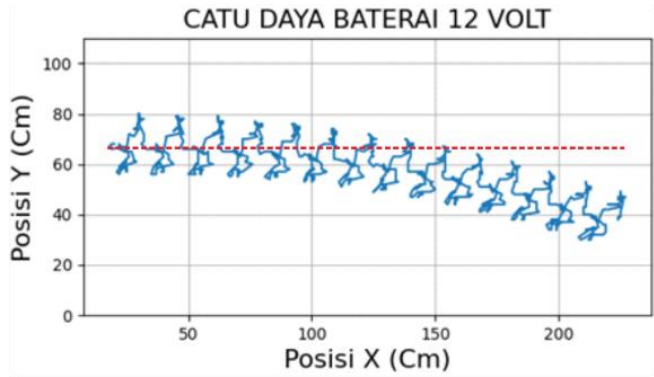

(c)

Figure 10. Battery Power Supply 12.6V, (b) Battery Power Supply 12.3V (c) Battery Power Supply $12 \mathrm{~V}$

This test is carried out using the slope of the competition arena to see the level of success of the robot before using the control system. The test results are shown in Fig. 11. Based on this 
test, it can be seen that the movement of the robot is tilted several degrees from the red straight line reference.

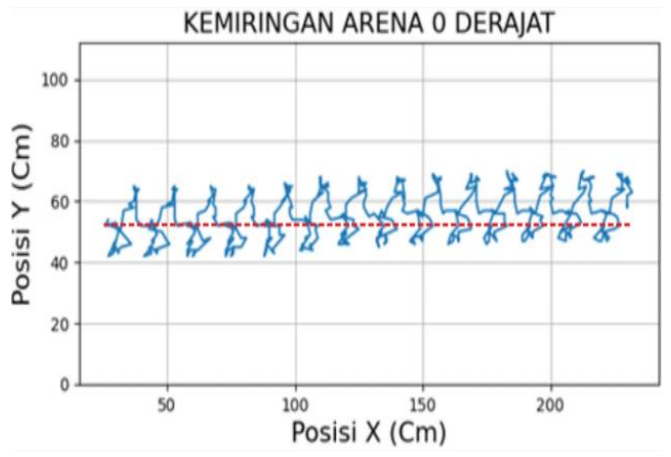

(a)

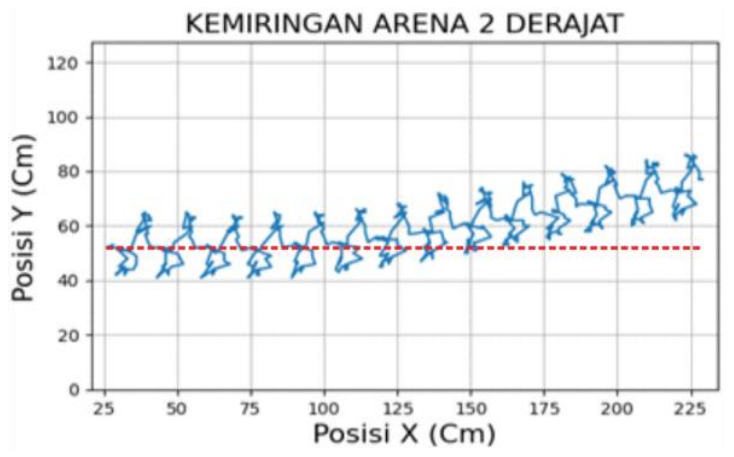

(b)

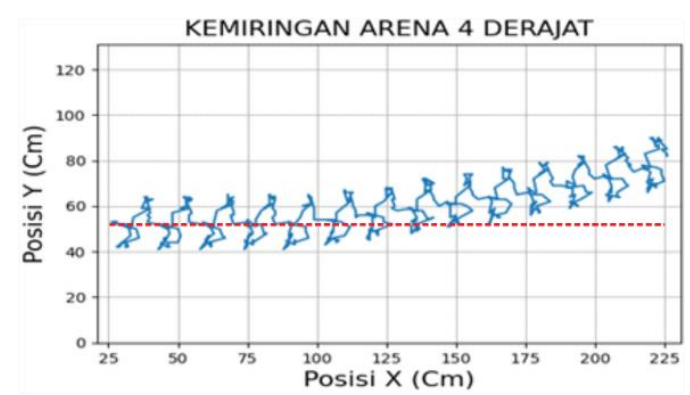

(c)

Figure 11. (a) Arena slope $0^{\circ}$, (b) Arena slope $2^{\circ}$, (c) Arena slope $4^{\circ}$

\subsection{Proposed Controller}

This test is carried out using a battery power supply condition to see the success rate of the robot after using the control system. The robot will be recorded and the video recording will be used as material in the object marking process using the python application and the results of the plotting of the robot's movement will be obtained in the race arena. The test results are shown in Fig. 12. Based on this test the proposed controller has been able to reduce the tilt level of the robot to move straight following a straight line reference.

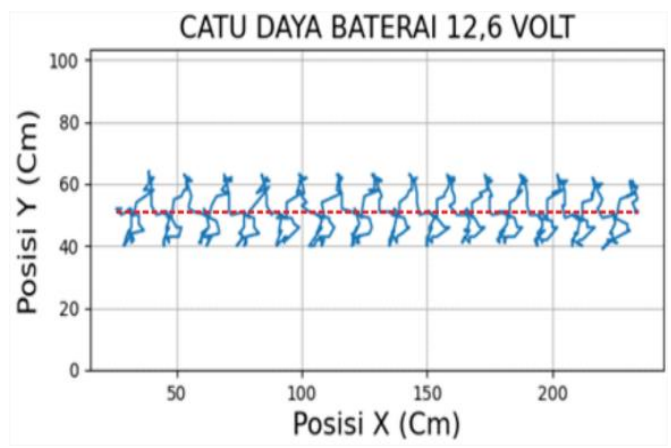

(a)

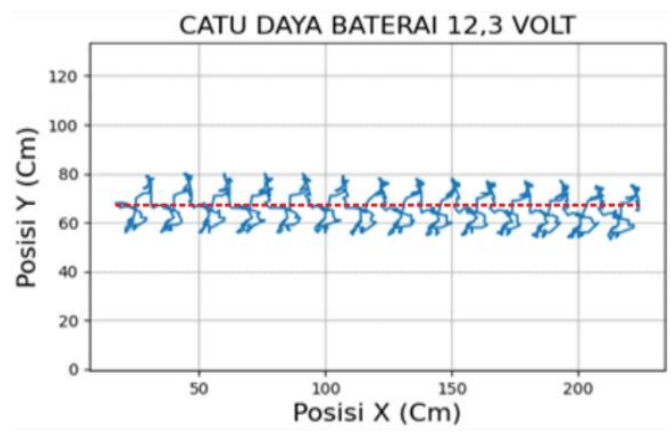

(b) 


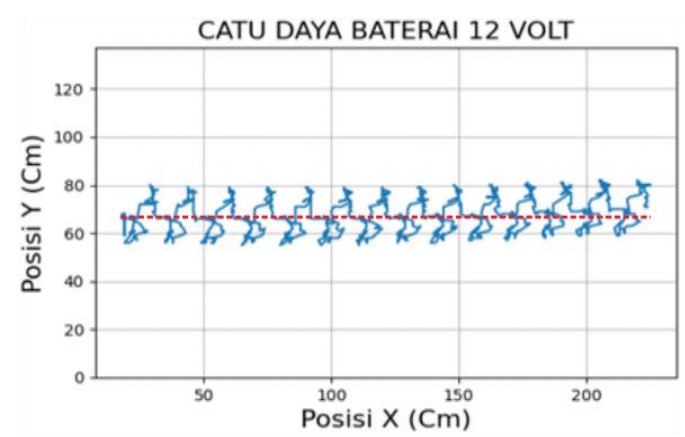

(c)

Figure 12. (a) Battery Power Supply 12.6V (b) Battery Power Supply 12.3V (c) Battery Power Supply $12 \mathrm{~V}$

In this test, it is carried out by providing a slope condition in the race arena to see the success rate of the comparison of robots after using the control system. The test results are shown in Fig. 13. Based on this test the proposed controller has been able to reduce the tilt level of the robot to move straight following a straight line reference.

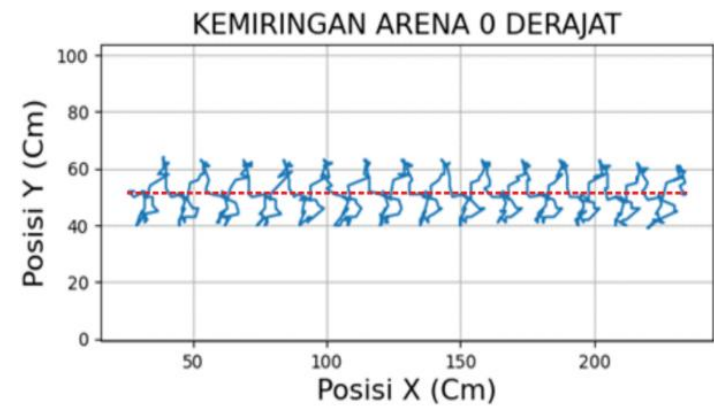

(a)

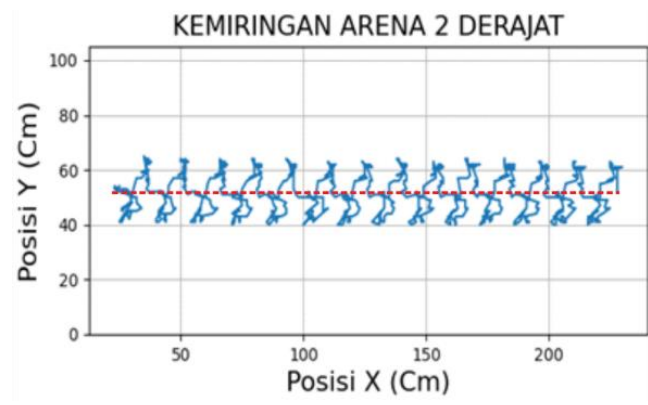

(b)

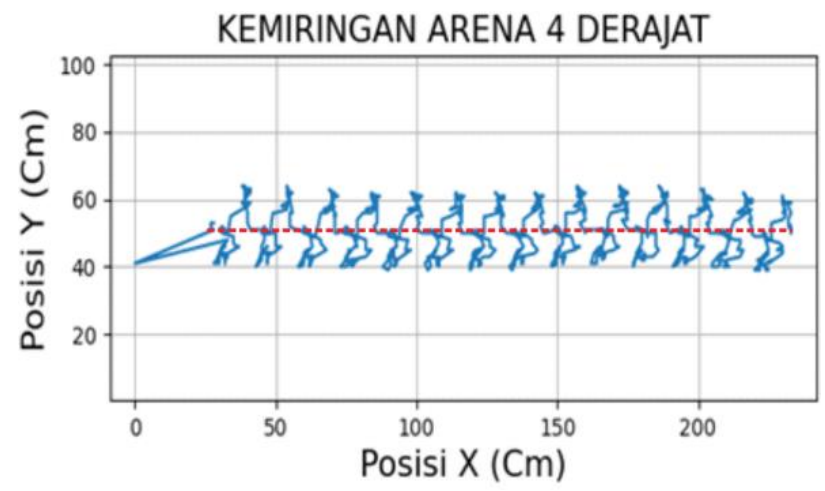

(c)

Figure 13. Arena Slope $0^{\circ}(\mathrm{b})$ Arena Slope $2^{\circ}$ (c) Arena Slop $4^{\circ}$

\subsection{Battery Power Supply Test}

In this test, it is carried out using a 12.6 volt battery power supply to see the success rate of the robot after using the control system. The test results are shown in Table 5. 
Table 5. Testing with a $12.6 \mathrm{volt}$ battery power supply

\begin{tabular}{|c|c|c|c|c|}
\hline No & Initial Angle $\left(^{\circ}\right)$ & |Final Angle $\mid\left(^{0}\right)$ & Error $\left(^{(}\right)$ & Information \\
\hline 1 & 0 & 2 & 2 & $\sqrt{ }$ (success) \\
\hline 2 & 0 & 2 & 2 & $\sqrt{ }$ (success) \\
\hline 3 & 0 & 2 & 2 & $\sqrt{ }$ (success) \\
\hline 4 & 0 & 2 & 2 & $\sqrt{ }$ (success) \\
\hline 5 & 0 & 3 & 3 & $\sqrt{ }$ (success) \\
\hline \multicolumn{3}{|c|}{ |Average Error| } & 2.2 & \\
\hline
\end{tabular}

In this test, it was carried out using a 12.3 volt battery power supply to see the success rate of the robot after using the control system. The test results are shown in Table 6.

Table 6. Testing with a 12.3 volt battery power supply

\begin{tabular}{|c|c|c|c|c|}
\hline No & Initial Angle $\left(^{\circ}\right)$ & $\mid$ Final Angle $\mid\left(^{\circ}\right)$ & |Error $\left(^{(0)}\right.$ & Information \\
\hline 1 & 0 & 2 & 2 & $\sqrt{ }$ (success) \\
\hline 2 & 0 & 2 & 2 & $\sqrt{ }$ (success) \\
\hline 3 & 0 & 4 & 4 & $\sqrt{ }$ (success) \\
\hline 4 & 0 & 2 & 2 & $\sqrt{ }$ (success) \\
\hline 5 & 0 & 2 & 2 & $\sqrt{ }$ (success) \\
\hline \multicolumn{3}{|c|}{ |Average Error| } & 2.4 & \\
\hline
\end{tabular}

In this test, it is carried out using a 12 volt battery power supply to see the success rate of the robot after using the control system. The test results are shown in Table 7.

Table 7. Testing with a 12 volt battery power supply

\begin{tabular}{|c|c|c|c|c|}
\hline No & Initial Angle $\left(^{0}\right)$ & $\mid$ Final Angle $\left.\left.\right|^{(}\right)$ & |Error| ( $\left(^{\mathbf{0}}\right)$ & Information \\
\hline 1 & 0 & 3 & 3 & $\sqrt{ }$ (success) \\
\hline 2 & 0 & 3 & 3 & $\sqrt{ }$ (success) \\
\hline 3 & 0 & 2 & 2 & $\sqrt{ }$ (success) \\
\hline 4 & 0 & 4 & 4 & $\sqrt{ }$ (success) \\
\hline 5 & 0 & 3 & 3 & $\sqrt{ }$ (success) \\
\hline \multicolumn{3}{|c|}{ |Average Error| } & 3 & \\
\hline
\end{tabular}

The percentage of successful testing is shown in Table 8. The average percentage of success of the Lanange Jagad dance robot with a robot control system capable of finishing using a battery power supply of 12 volts to 12.6 volts is $100 \%$.

Table 8. Percentage of successful testing

\begin{tabular}{cc}
\hline Battery Power Supply (volt) & Percentage of Success (\%) \\
\hline 12.6 & 100 \\
11.9 & 100 \\
12 & 100 \\
\hline Average & 100 \\
\hline
\end{tabular}

\subsection{Testing with the Slope of the Race Arena}

In this test, it is done by giving a slope to the $0^{\circ}$ race arena to see the success rate of the robot after using the control system. The test results are shown in Table 9. Based on the examination, the test has one hundred successes for 5 examinations. 
Table 9. Tests with the slope of the race arena $0^{\circ}$

\begin{tabular}{|c|c|c|c|c|}
\hline No & Initial Angle $\left(^{\circ}\right)$ & | Final Angle | $\left(^{\circ}\right)$ & |Error| $\left(^{0}\right)$ & Information \\
\hline 1 & 0 & 2 & 2 & $\sqrt{ }($ successful $)$ \\
\hline 2 & 0 & 2 & 2 & $\sqrt{ }($ successful $)$ \\
\hline 3 & 0 & 2 & 2 & $\sqrt{ }($ successful $)$ \\
\hline 4 & 0 & 2 & 2 & $\sqrt{ }($ successful $)$ \\
\hline 5 & 0 & 3 & 3 & $\sqrt{ }($ successful $)$ \\
\hline
\end{tabular}

In this test, it is done by giving a $2^{\circ}$ slope to the race arena to see the success rate of the robot after using the control system. The test results are shown in Table 10.

Table 10. Testing with the slope of the race arena $2^{\circ}$

\begin{tabular}{|c|c|c|c|c|}
\hline No & Initial Angle $\left(^{\circ}\right)$ & | Final Angle | $\left(^{\circ}\right)$ & $\mid$ Error| $\left(^{0}\right)$ & Information \\
\hline 1 & 0 & 2 & 2 & $\sqrt{ }($ successful $)$ \\
\hline 2 & 0 & 2 & 2 & $\sqrt{ }($ successful $)$ \\
\hline 3 & 0 & 3 & 3 & $\sqrt{ }($ successful $)$ \\
\hline 4 & 0 & 3 & 3 & $\sqrt{ }($ successful $)$ \\
\hline 5 & 0 & 3 & 3 & $\sqrt{ }($ successful $)$ \\
\hline
\end{tabular}

In this test, it is carried out by providing a slope in the $4^{\circ}$ race arena to see the success rate of the robot after using the control system. The test results are shown in Table 11.

Table 11. Testing with the slope of the race arena $4^{\circ}$

\begin{tabular}{|c|c|c|c|c|}
\hline No & Initial Angle $\left(^{0}\right)$ & | Final Angle | $\left(^{\circ}\right)$ & |Error| $\left(^{\circ}\right)$ & Information \\
\hline 1 & 0 & 3 & 3 & $\sqrt{ }($ successful $)$ \\
\hline 2 & 0 & 5 & 5 & $X$ (not successful) \\
\hline 3 & 0 & 3 & 3 & $\sqrt{ }($ successful $)$ \\
\hline 4 & 0 & 2 & 2 & $\sqrt{ }($ successful $)$ \\
\hline 5 & 0 & 3 & 3 & $\sqrt{ }($ successful $)$ \\
\hline
\end{tabular}

The percentage of successful testing is shown in Table 12. The average percentage of success of the Lanange Jagad dance robot with a robot control system being able to finish when it gets an arena slope of $0^{\circ}$ to $4^{\circ}$ is $93.3 \%$.

Table 12. Percentage of test success

\begin{tabular}{cc}
\hline Battery Power Supply (volt) & Percentage of Success (\%) \\
\hline 0 & 100 \\
2 & 100 \\
4 & 80 \\
\hline Average & 93.3 \\
\hline
\end{tabular}

\section{Conclusions}

From the results of the overall test of the Lanange Jagad dance robot after adding the road direction control system, the percentage of the success rate in the battery power supply condition is 12 volts to 12.6 volts by $100 \%$ with the greater the battery power supply, the average error of the robot's final angle to it. the starting angle of the robot is getting smaller and 
the percentage of the success rate at the slope of the 0 o to 40 race arena is $93.3 \%$. With the tilted race arena, the average error of the robot's final angle to the starting angle of the robot is also getting bigger, so it can be concluded that the robot can be controlled. direction of motion and can be stable finish in the closed zone.

\section{Acknowledgement}

Thank you to those who have helped and motivated the preparation of this article, both morally and materially.

\section{References}

[1] N. Satrio Pambudi, D. Made Wiharta, N. Putra Satra, J. Teknik Elektro, and F. Teknik Universitas Udayana, "Analisa Kestabilan Gerakan Statis Pada Robot Humanoid," E-Journal SPEKTRUM, vol. 5, no. 2, pp. 253-262, 2018. https://doi.org/10.24843/SPEKTRUM.2018.v05.i02.p32

[2] D. P. Sinaga, E. Susanto, and R. Nugraha, "Rancang Bangun Kestabilan Posisi Sistem Kendali Manual Robot Kapal Selam Menggunakan Metode Fuzzy Logic," Skripsi Universitas Telkom Bandung, 2016. https://openlibrary.telkomuniversity.ac.id/pustaka/110034/rancang-bangun-kestabilan-posisisistem-kendali-manual-robot-kapal-selam-menggunakan-metode-fuzzy-logic.html

[3] R. Andianto, R. Maulana, and G. E. Setyawan, "Perancangan dan Implementasi Sistem Pola Berjalan Pada Robot Humanoid Menggunakan Metode Inverse Kinematic," J. Pengemb. Teknol. Inf. dan Ilmu Komput., vol. 2, no. 8, pp. 2753-2760, 2018. http://j-ptiik.ub.ac.id/index.php/jptiik/article/download/1958/753/

[4] M. Ainur Fahd, D. Purwanto, M. Hilman Fatoni, D. Teknik Elektro, F. Teknologi Elektro, and I. Teknologi Sepuluh Nopember, "Rancang Bangun Robot Penari Humanoid dengan 25 DoF untuk Melakukan Gerakan Tari Remo," J. Tek. ITS, vol. 7, no. 2, 2018. https://doi.org/10.12962/j23373539.v7i2.30965

[5] I. Maulana and N. S. Widodo, "Sistem Pengolah Musik Sebagai Kontrol Gerak Robot Humanoid," Buletin Ilmiah Sarjana Teknik Elektro, vol. 1, no. 2, p. 46, 2019. https://doi.org/10.12928/biste.v1i2.915

[6] B. Firman, "Implementasi Sensor IMU MPU6050 Berbasis Serial I2C pada Self-Balancing Robot," J. Teknol. Technoscientia, vol. 9, no. 1, pp. 18-24, 2016. https://ejournal.akprind.ac.id/index.php/technoscientia/article/view/145

[7] A. S. Samosir and N. S. Widodo, "Gyroscope and Accelerometer Sensor on the Lanange Jagad Dance Robot Balance System," Buletin Ilmiah Sarjana Teknik Elektro, vol. 2, no. 2, pp. 51-58, 2020. https://doi.org/10.12928/biste.v2i2.922

[8] M. R. Chandra, M. S. Suraatmadja, R. Nugraha, "Rancang Bangun Alat Pengatur Arah Kamera Berdasarkan Pergerakan Kepala Berbasis Sensor Gyroscope," Skripsi Universitas Telkom Bandung, 2016. https://openlibrary.telkomuniversity.ac.id/pustaka/116892/rancang-bangun-alatpengatur-arah-kamera-berdasarkan-pergerakan-kepala-berbasis-sensor-gyroscope.html

[9] R. I. Alfian, A. Ma'arif, and S. Sunardi, "Noise Reduction in the Accelerometer and Gyroscope Sensor with the Kalman Filter Algorithm," Journal of Robotics and Control (JRC), vol. 2, no. 3, pp. 180-189, 2021. https://doi.org/10.18196/jrc.2375

[10] A. Jefiza, "Sistem Pendeteksi Jatuh Berbasis Sensor Gyroscope dan Sensor Accelerometer Menggunakan Backpropagation," Tesis Respository ITS, 2017. http://repository.its.ac.id/44739/

[11] A. H. Kurniawan, M. Rivai, F. Teknik Elektro, and I. Teknologi Sepuluh Nopember, "Sistem Stabilisasi Nampan Menggunakan IMU Sensor Dan Arduino Nano," J. Tek. ITS, vol. 7, no. 2, 2019. https://doi.org/10.12962/j23373539.v7i2.31043

[12] M. N. Qomarudin, "Memahami Sudut Euler dan Matriks Rotasi," Technical Report, 2017. https://doi.org/10.13140/RG.2.2.27123.43040

[13] S. Soim and B. Joni, "Perancang Robot Humanoid Berbasis Mikrokontroler Atmega 32," Semin. Nas. Sains dan Teknol., no. November, pp. 1-6, 2015. https://doi.org/10.31851/ampere.v1i2.898 